\title{
Comparison of androgen receptor and oestrogen receptor $\beta$ immunoexpression in the testes of the common marmoset (Callithrix jacchus) from birth to adulthood: low androgen receptor immunoexpression in Sertoli cells during the neonatal increase in testosterone concentrations
}

\author{
C. McKinnell ${ }^{1}$, P. T. K. Saunders ${ }^{1}$, H. M. Fraser ${ }^{1}$, C. J. H. Kelnar ${ }^{2}$, \\ C. Kivlin ${ }^{1}$, K. D. Morris ${ }^{1}$ and R. M. Sharpe ${ }^{1}$ \\ ${ }^{1}$ MRC Human Reproductive Sciences Unit, Centre for Reproductive Biology, 37 Chalmers \\ Street, Edinburgh EH3 9ET, UK; and ${ }^{2}$ Section of Child Life and Health, Department of \\ Reproductive and Developmental Sciences, University of Edinburgh, Edinburgh EH9 1UW, UK
}

The aims of this study were: (i) to investigate the cellular immunoexpression of androgen receptor and oestrogen receptor $\beta$ in the testes of the common marmoset (Callithrix jacchus) during neonatal life compared with their expression at later ages; (ii) to establish whether neonatal marmoset Sertoli cells are targets for androgens or oestrogens or both; and (iii) to investigate the relationship between neonatal plasma testosterone concentrations and androgen receptor immunoexpression by abolishing the neonatal testosterone surge with a potent $\mathrm{GnRH}$ antagonist. Androgen receptor and oestrogen receptor $\beta$ immunoexpression were evaluated in neonatal animals aged 1-4 days, 4 weeks and 6 weeks, and compared with immunoexpression in animals aged 18-22 weeks (early infancy), 35 weeks (late infancy), 58-62 weeks (late pubertal) and $>100$ weeks (adult). Immunoexpression of androgen receptor in the reproductive tract was also evaluated at each age. Sertoli cell immunoexpression of androgen receptor was weak or absent in neonatal animals, but increased substantially in infant animals, reaching adult levels by the end of infancy. In contrast, immunoexpression of androgen receptor during the neonatal period was strong in testicular interstitial cells and very strong in epithelial cell nuclei throughout the reproductive tract, and did not change greatly with age in these cells or tissues. Similarly, immunoexpression of oestrogen receptor $\beta$ was prominent in many Sertoli cells and in the germ cells of neonatal animals, and was relatively constant throughout life. Weak immunoexpression of androgen receptor in neonatal Sertoli cells was associated with high plasma testosterone concentrations (2.7-5.5 $\mathrm{ng} \mathrm{ml}^{-1}$ ), whereas strong Sertoli cell immunoexpression was associated with baseline (approximately $0.12 \mathrm{ng} \mathrm{ml}^{-1}$ ) testosterone concentrations in infant animals and with $>10 \mathrm{ng} \mathrm{ml}^{-1}$ in late pubertal and adult animals. Immunoexpression of androgen receptor and oestrogen receptor $\beta$ was also evaluated in co-twin males aged 4 and 35 weeks, after treatment from birth to 4 weeks or from week 25 to week 35, respectively, with either vehicle or with $\mathrm{GnRH}$ antagonist at a dose known to suppress the neonatal testosterone surge completely. Only GnRH antagonist treatment during weeks 25-35 reduced androgen receptor immunoexpression, whereas immunoexpression of oestrogen receptor $\beta$ was unaffected by treatment during either period. On the basis of these findings it is suggested that: (i) neonatal marmoset Sertoli cells may be targets primarily for oestrogens rather than androgens; (ii) androgen receptor expression in the testes of neonatal and infant marmosets is not regulated in a straightforward way by testosterone; and (iii) high neonatal concentrations of plasma testosterone are not absolutely necessary for expression of androgen receptor in marmoset testes at this time.

\section{Introduction}

Male marmosets present a potentially useful model for study of the regulation of testicular function in humans. In both humans and marmosets the testes are descended into the

Email: c.mckinnell@hrsu.mrc.ac.uk scrotum at the time of birth and a period of neonatal testicular activity characterized by a transient increase ('neonatal surge') in plasma testosterone concentrations (Forest et al., 1976; Dixson, 1986; Lunn et al., 1994) and Sertoli cell proliferation (Cortes et al., 1987; Sharpe et al., 2000) is followed by a relatively quiescent and extended 'childhood' or 'infancy' phase. In both marmosets (Sharpe 
et al., 2000) and humans (Cortes et al., 1987), Sertoli cell proliferation can also occur later than the neonatal period. In addition, there are similarities in the organization of spermatogenesis between adult marmosets and humans (Saunders et al., 1996a; Millar et al., 2000; Weinbauer et al., 2001).

The physiological significance of the neonatal surge in testosterone concentrations is unclear. The bioavailability of between $11 \%$ and $30 \%$ of plasma testosterone in neonatal marmosets indicates that it has the potential to influence cell function (Lunn et al., 1997). Blocking this increase by neonatal treatment with a GnRH antagonist results in attenuation of the pubertal increase in plasma testosterone concentrations (Lunn et al., 1994), alterations in the development of the cell-mediated immune system (Mann et al., 1998, 1999) and, in adults, an increase in Leydig cell volume per testis and a modest decrease in germ cell volume per Sertoli cell (Sharpe et al., 2000). However, there are no apparent long-term consequences in terms of adult male sexual behaviour (Lunn et al., 1994) or fertility (Lunn et al., 1997).

Puberty in marmosets and humans is characterized by a marked increase in plasma testosterone from baseline concentrations (Dixson, 1986; Lunn et al., 1994; Rey, 1999), which in marmosets normally begins between week 25 and week 36 of age, and lasts until weeks 57-70 of age (Abbott and Hearn, 1978; Lunn et al., 1994). Studies in rats show that androgen receptor expression in Sertoli cells is switched on at about the time of puberty (Bremner et al., 1994), and our own preliminary studies (C. McKinnell and R. M. Sharpe, unpublished) indicate that the same is true in marmosets. However, there are no data on the cellular location of androgen receptor expression in neonatal human males or primates in which there is a neonatal testosterone surge, and it is therefore not known whether Sertoli cells are an androgen target at this age.

Therefore, the first aim of the present study was to investigate androgen receptor expression in neonatal marmoset testes compared with its expression at later ages. The second aim was to elucidate further the biological significance of the neonatal testosterone surge by investigating the effect of treatment with a $\mathrm{GnRH}$ antagonist from birth to week 4 of age (when plasma testosterone concentrations are high) on androgen receptor expression in the testis and reproductive tract compared with treatment from weeks 25-35 of age (when testosterone concentrations are baseline).

Recent studies have detected multicellular expression of oestrogen receptor $\beta$ in the testes of adult humans and nonhuman primates (Taylor and Al-Azzawi, 2000; Saunders et al., 2001), while previous studies in rodents have shown that oestrogen receptor $\beta$, but not oestrogen receptor $\alpha$, is expressed in the Sertoli cells and most germ cells of immature mice (Jefferson et al., 2000), and throughout life in other species (Saunders et al., 1998; van Pelt et al., 1999; Bilinska et al., 2000). Therefore, oestrogen receptor $\beta$ expression in the testes was also evaluated to determine whether marmoset Sertoli cells are either primarily or exclusively androgen or oestrogen targets during the neonatal period.

\section{Materials and Methods}

\section{Animals and treatments}

Animals were captive-bred common marmoset monkeys (Callithrix jacchus), maintained in a closed breeding colony that has been self-sustaining since 1973 . The primary use of the animals from which testes were obtained for the present study was in various other studies (for example, Lunn et al., 1994, 1997), except for newborn (aged 1-4 days) animals, which were killed because they originated from triplet births (with triplets, only two animals usually survive). Tissue from four or five animals at each age (1-4 days and 4 , $6,18-22,35,58-62$ and > 100 weeks) was used. In addition to control animals, at weeks 4 and 35 animals treated with a GnRH antagonist were also used and, again, the primary use of these animals was in other studies. As there is considerable variation among individual marmosets in parameters related to testis size and development, the $\mathrm{GnRH}$ antagonist studies used male co-twins: vehicle was administered to one co-twin as a control and a long-acting $\mathrm{GnRH}$ antagonist was administered to the other co-twin at a dose of $10 \mathrm{mg} \mathrm{kg}^{-1}$ in propylene glycol: water $(1: 1, \mathrm{v} / \mathrm{v})$. In $\mathrm{GnRH}$ antagonist-treated animals sampled at 4 weeks of age, the GnRH antagonist used was Antide (Contraceptive Development Branch, Center for Population Research, NICHD) and it was injected s.c. on the day of birth, days 3 and 7 after birth, and then at 1 week intervals up to 4 weeks. Earlier studies have shown that this treatment regimen effectively suppresses $\mathrm{LH}$ secretion and abolishes the normal neonatal increase in testosterone concentrations due to regression of the Leydig cells (Lunn et al., 1994, 1997). In GnRH antagonist-treated animals sampled at 35 weeks of age, the GnRH antagonist administered was Antarelix (Europeptides, Argentuil) and this was administered once a week beginning at age 25 weeks. Antarelix has similar properties and duration of action to Antide and studies of the treated animals have shown that testis development is retarded as a result of the $\mathrm{GnRH}$ antagonist treatment (R. M. Sharpe, C. McKinnell, K. Morris and C. Kelnar, unpublished). In both experiments, propylene glycol: water $(1: 1, v / v)$ vehicle only was administered to the control co-twins.

These studies were performed under UK Home Office project licence and with local ethical committee approval.

\section{Tissue collection and processing}

Testes with epididymides attached were fixed by immersion for $5.5 \mathrm{~h}$ in Bouin's fixative, the two tissues were dissected free of each other and of connective tissue, and the testes were weighed. Tissue was then transferred to $70 \%$ $(\mathrm{v} / \mathrm{v})$ ethanol before being processed and embedded in paraffin wax using standard techniques. 


\section{Antibodies used for immunohistochemistry}

A rabbit polyclonal antibody (Santa Cruz Biotechnology Inc., Santa Cruz, CA) raised against an epitope at the $\mathrm{N}$-terminus of human androgen receptor was used at a dilution of 1:2000 for immunolocalization of androgen receptor. Oestrogen receptor $\alpha$ was immunolocalized using a mouse monoclonal antibody raised against a full-length human oestrogen receptor $\alpha$ recombinant protein (Novocastra, Newcastle upon Tyne) at a dilution of 1:20. Oestrogen receptor $\beta$ was immunolocalized using an affinity-purified polyclonal anti-peptide IgG raised in sheep against a specific peptide in the hinge (D) domain of human oestrogen receptor $\beta$ as described by Saunders et al. (2000); it was used at a dilution of 1:1000. Rigorous evaluation of the specificity of the antibodies used, based on western blot analyses and pre-absorption, has been detailed in our previous studies (Saunders et al., 2000; Williams et al., 2000; McKinnell et al., 2001).

\section{Immunohistochemistry}

Unless otherwise stated, all incubations were performed at room temperature. Paraffin wax was removed from the sections using Histoclear (National Diagnostics, Hull), rehydrated in a graded ethanol series and washed in water. At this stage, sections were subjected to a temperatureinduced antigen retrieval step (Norton et al., 1994) in either

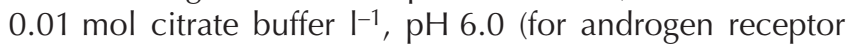
and oestrogen receptor $\alpha$ ), or 0.5 mol glycine ${ }^{-1}, \mathrm{pH}^{3} .5$, and $0.01 \%(\mathrm{w} / \mathrm{v})$ EDTA (for oestrogen receptor $\beta$ ). After pressure cooking for $5 \mathrm{~min}$ at full pressure, sections were left to stand, undisturbed, for $20 \mathrm{~min}$, cooled under running tap water and washed twice (5 min each) in Tris-buffered saline (TBS; 0.05 mol Tris- $\mathrm{HCl} \mathrm{I-1}, \mathrm{pH} 7.4,0.85 \%$ (w/v) $\mathrm{NaCl}$ ). Endogenous peroxidase activity was blocked by immersing all sections in $3 \%(\mathrm{v} / \mathrm{v}) \mathrm{H}_{2} \mathrm{O}_{2}$ in methanol (both from BDH Laboratory Supplies, Poole) for $30 \mathrm{~min}$, which was followed by two $5 \mathrm{~min}$ washes in TBS. Sections were incubated for $30 \mathrm{~min}$ with the appropriate normal serum diluted 1:5 in TBS containing 5\% (w/v) BSA (Sigma, Poole) to block non-specific binding sites. For androgen receptor, normal swine serum (NSW) was used and for oestrogen receptor $\alpha$ and oestrogen receptor $\beta$, normal rabbit serum (NRS) was used (both from Diagnostics Scotland, Carluke). Primary antibodies were added to the sections at the appropriate dilution in either NSW-TBS-BSA (for androgen receptor) or NRS-TBS-BSA (for oestrogen receptor $\alpha$ and oestrogen receptor $\beta$ ) and incubated overnight at $4^{\circ} \mathrm{C}$ in a humidified chamber, followed by two 5 min washes in TBS. For androgen receptor and oestrogen receptor $\alpha$, sections were incubated for $30 \mathrm{~min}$ with anti-rabbit or anti-mouse horseradish peroxidase-labelled polymer (EnVision; DAKO, Ely), respectively. For oestrogen receptor $\beta$, sections were incubated for $30 \mathrm{~min}$ with biotinylated rabbit anti-sheep IgG (Vector Laboratories, Peterborough), washed twice (5 min each) in TBS, and incubated for a further 30 min with avidin-biotin conjugated to horseradish peroxidase
(DAKO) diluted in 0.05 mol Tris- $\mathrm{HCl} \mathrm{I}^{-1}, \mathrm{pH} 7.4$, according to the manufacturer's instructions. All sections were washed twice (5 min each) in TBS and immunostaining was developed using Liquid DAB+ (DAKO) until staining was optimal, when the reaction was stopped by immersing sections in distilled water. All sections were lightly counterstained with haematoxylin, dehydrated in a graded ethanol series, cleared in xylene and covered with a coverslip using Pertex mounting medium (CellPath plc, Hemel Hempstead). As negative controls, slides were processed as above except that the appropriate normal serum was substituted for the primary antibody. Tissue sections from four or five animals at each age or treatment group were evaluated and this was performed on at least two separate occasions to ensure the reproducibility of findings.

Immunostained sections were examined and photographed using a Provis microscope (Olympus Optical, London) fitted with a digital camera (DCS330; Eastman Kodak, Rochester, NY). Captured images were transferred to a computer (G4; Apple Computer Inc., Cupertino, CA) and compiled using Photoshop 5.0 (Adobe Systems Inc., Mountain View, CA) before being printed using an Epson Stylus 870 colour printer (Seiko Epson Corp., Nagano).

\section{Measurement of testosterone concentrations}

Testosterone concentrations in plasma from control animals were measured using an ELISA adapted from an earlier radioimmunoassay (Corker and Davidson, 1981) as described elsewhere (Atanassova et al., 1999). The limit of detection was $12 \mathrm{pg} \mathrm{ml}^{-1}$.

\section{Results}

\section{Plasma concentrations of testosterone}

Plasma testosterone concentrations were measured at intervals of approximately 1 week from 1 week of age until adulthood ( $>100$ weeks of age) in five to eight animals to determine the relationship between androgen receptor immunoexpression and testosterone concentrations. Plasma testosterone concentrations fluctuated between approximately 2.7 and $5.5 \mathrm{ng} \mathrm{ml}^{-1}$ between week 1 and week 7 of age, before decreasing rapidly to approximately $1.5 \mathrm{ng} \mathrm{ml}^{-1}$ at week 8 of age (Fig. 1). Thereafter, the concentrations continued to decrease more slowly to approximately $0.12 \mathrm{ng} \mathrm{ml}^{-1}$ by week 16 of age and remained at this low concentration in all animals at week 35 of age (late infancy), before increasing again in late pubertal (weeks 58-62) animals, and then reaching concentrations in adulthood that were consistently $>10 \mathrm{ng} \mathrm{ml}^{-1}$ (Fig. 1).

\section{Immunoexpression of androgen receptor}

Immunoexpression of androgen receptor in the testes of marmosets aged 1-4 days, 4 weeks and 6 weeks was 


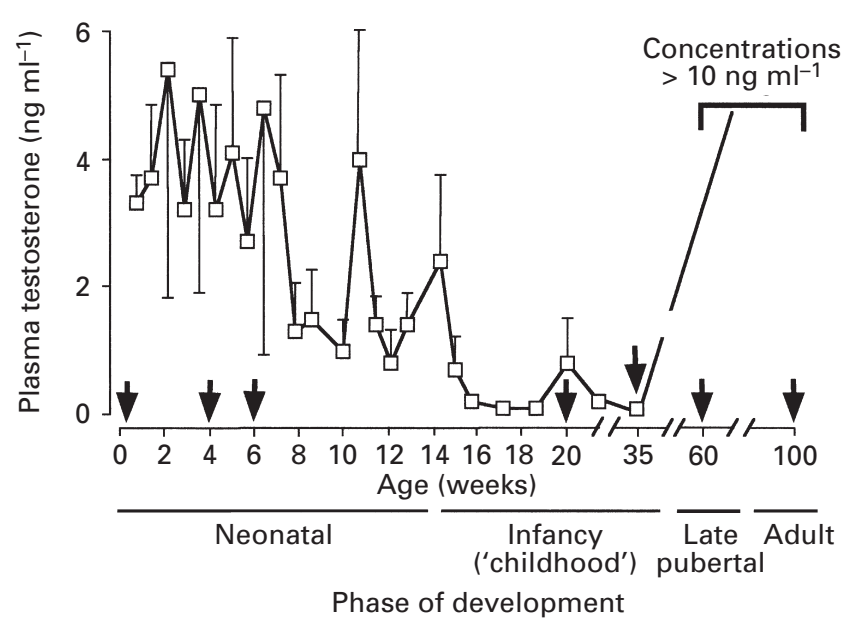

Fig. 1. Plasma testosterone concentrations in normal marmosets from neonatal life to adulthood. Values are mean \pm SEM $(n=5-8$ animals). Arrows indicate approximate ages at which samples were collected for immunohistochemical analysis.

evaluated to determine the location of androgen receptor expression during the neonatal period and compared with that in animals aged 18-22 weeks (early infancy), 35 weeks (late infancy), 58-62 weeks (late pubertal) and > 100 weeks (adult) (Table 1 and Fig. 2). In neonatal animals, weak nuclear immunoexpression of androgen receptor was detected in some, but not all, Sertoli cells (Fig. 2). Although quantitative analysis was not performed, the number of immunopositive Sertoli cells appeared to be greater at weeks 4 and 6 of age than at days $1-4$ of age. At weeks 18-22 of age, moderate or strong immunoexpression of androgen receptor was found in the nuclei of almost all Sertoli cells (Fig. 2), with some variation in the intensity of immunostaining between animals, whereas at week 35 of age and at all subsequent ages, strong immunoexpression of androgen receptor was observed consistently in Sertoli cells (Fig. 2). In contrast to Sertoli cells, strong immunoexpression of androgen receptor was observed in interstitial cells during the neonatal period, as well as at all later ages (Fig. 2). Similarly, immunoexpression of androgen receptor in epithelial cell nuclei in the efferent ducts (not shown), epididymis (Fig. 3), and in the vas deferens and prostatic buds (not shown) was very strong throughout the neonatal period. The intensity of androgen receptor immunostaining in the epididymis did not change greatly with age, remaining very strong throughout infancy and puberty (Fig. 3) and adulthood (not shown).

\section{Immunoexpression of oestrogen receptor $\beta$ and oestrogen receptor $\alpha$}

The immunoexpression of oestrogen receptors in marmoset testis was also evaluated to determine whether the Sertoli cells are preferential targets for oestrogen (Table 2 and Fig. 4). In contrast to the weak immunoexpression of androgen receptor at age 1-4 days, 4 weeks and 6 weeks, moderate or strong immunoexpression of oestrogen receptor $\beta$ was detected in most of the Sertoli cells at these ages (Fig. 4). Strong immunoexpression of oestrogen receptor $\beta$ was also detected in the germ cells and in some interstitial cells at these ages (Fig. 4). Oestrogen receptor $\beta$ immunoexpression did not vary greatly with age, and the pattern of immunoexpression at all later ages was broadly similar to that found in neonatal animals (Fig. 4). Immunoexpression of oestrogen receptor $\beta$ was detected in most types of germ cell and immunostaining in these cells appeared to be more intense than that in Sertoli cells, whereas in the late pubertal and adult testes, the immunostaining appeared to be most intense in spermatogonia and round spermatids (Fig. 4).

In contrast, no immunoexpression of oestrogen receptor $\alpha$ was detected within the seminiferous tubules at any age studied (Fig. 4), although there was intense immunoexpression in the epithelium of the efferent ducts (not shown). However, immunoexpression was detected in a few testicular interstitial cells at all ages, in which the immunostaining was diffuse and appeared to be located in the cytoplasm rather than in the nucleus (Fig. 4). Fisher et al. (1997) reported a similar pattern of cytoplasmic oestrogen receptor $\alpha$ immunoexpression in marmoset interstitial cells.

\section{Effect of treatment with GnRH antagonist on immunoexpression of androgen receptor and oestrogen receptor $\beta$}

The effect of treatment of co-twin males with vehicle (controls) or $\mathrm{GnRH}$ antagonist either from birth to week 4 of age (when testosterone concentrations are normally high) or from week 25 to week 35 of age (when testosterone concentrations are at baseline) was investigated to determine whether androgen receptor immunoexpression in Sertoli and other cells is dependent on the neonatal increase in plasma testosterone concentrations. GnRH antagonist was used at a dose known to suppress the neonatal testosterone surge completely (Lunn et al., 1994, 1997). GnRH antagonist treatment had no clear or consistent effect on androgen receptor immunoexpression in animals aged 4 weeks (Fig. 5), whereas androgen receptor immunoexpression was reduced moderately or substantially in the Sertoli cells in three of four 35-week-old treated animals compared with their control co-twins (Fig. $5)$; the degree of reduction was variable among animals. $\mathrm{GnRH}$ antagonist treatment also resulted in a reduction in androgen receptor immunoexpression in interstitial cells in some animals aged 35 weeks (Fig. 5). As it was possible that the variable degree of the reduction in androgen receptor immunostaining in animals aged 35 weeks might reflect variation among individual animals, the androgen receptor immunohistochemistry was repeated using an antibody dilution of 1:4000. At this dilution a substantial reduction in androgen receptor immunoexpression was apparent in all $\mathrm{GnRH}$ antagonist-treated animals compared with their respective control co-twins (results not shown). In contrast 
Table 1. Summary of androgen receptor immunoexpression in marmosets

\begin{tabular}{lcccc}
\hline & & \multicolumn{3}{c}{$\begin{array}{c}\text { Intensity of androgen } \\
\text { receptor immunoexpression* }\end{array}$} \\
\cline { 3 - 5 } Age & Stage of development & Sertoli cells & Interstitial cells & Epididymis \\
\hline $1-4$ days & Neonatal & \pm & $+/++$ & +++ \\
$4-6$ weeks & Neonatal & \pm & $+/++$ & +++ \\
$18-22$ weeks & Early infancy & $+/+$ & $+/++$ & +++ \\
35 weeks & Late infancy & ++ & $+/++$ & +++ \\
$58-62$ weeks & Late pubertal & ++ & $+/++$ & +++ \\
$>100$ weeks & Adult & ++ & $+/++$ & +++ \\
\hline
\end{tabular}

*Based on evaluation of four to five animals at each age. Immunoexpression was classified as: \pm : weak; +: moderate; ++ : strong; +++ : very strong.

to its effect on androgen receptor immunoexpression in the testis, GnRH antagonist treatment had no effect on androgen receptor immunoexpression in the epithelium of the epididymis at either week 4 (not shown) or week 35 of age (Fig. 5). In addition, GnRH antagonist treatment had no effect on oestrogen receptor $\beta$ immunoexpression in any type of cell in the testis, or in the epididymal epithelium, at any age (results not shown).

\section{Discussion}

The principal aim of the present study was to investigate androgen receptor and oestrogen receptor $\beta$ expression in the testes of the common marmoset (Callithrix jacchus) during neonatal life, compared with their expression at later ages, to determine whether neonatal marmoset Sertoli cells are a target for androgens or oestrogens, or both. A further aim was to elucidate the relationship between the neonatal increase in plasma testosterone concentrations and androgen receptor immunoexpression by abolishing the testosterone surge with a GnRH antagonist. This is the first study in which the cellular immunolocalization of androgen receptor and oestrogen receptor $\beta$ expression has been demonstrated in neonatal and immature marmoset testes. The results of the present study show that marmoset Sertoli cells express androgen receptor only weakly or not at all during the neonatal period, and that androgen receptor immunoexpression in most Sertoli cells increases substantially during the 'childhood' phase (weeks 18-35), reaching adult intensity towards the end of this period. In contrast, strong immunoexpression of oestrogen receptor $\beta$ was found in many Sertoli cells and in the germ cells of neonatal animals, and did not change greatly with age. Abolition of the normal increase in plasma testosterone concentrations during neonatal life had no effect on androgen receptor immunoexpression in neonatal marmosets, or on immunoexpression of oestrogen receptor $\beta$.

The cellular distribution of androgen receptor expression observed in the testes of adult marmosets in the present study is similar to that described by Saunders et al. (1996b), and to the pattern found in adult human testes by Suarez-
Quian et al. (1999), using different antibodies to those used in the present study. However, there are no previous data for androgen receptor expression in the testes of neonatal and immature marmosets or other non-human primates. The developmental pattern of androgen receptor immunoexpression found in the present study is similar to that reported for rat testis by Bremner et al. (1994). Bremner et al. (1994) also found prominent immunostaining in cells outside the seminiferous epithelium from day 5 of age onwards, whereas Sertoli cell immunostaining was weak at days 5 and 14 of age but increased progressively thereafter. Plasma testosterone concentrations in the present study also followed a developmental pattern similar to that described in previous studies of marmosets (Dixson, 1986; Lunn et al., 1994). Concentrations were high during the neonatal period (the 'neonatal surge'), but decreased rapidly thereafter, remained very low throughout infancy and did not increase again until the late pubertal period (weeks 58-62 of age). However, the pattern of androgen receptor immunoexpression in Sertoli cells in neonatal and infant marmosets was not correlated with the pattern of plasma testosterone concentrations. Thus, weak immunoexpression of androgen receptor in Sertoli cells during the neonatal period was associated with high concentrations of plasma testosterone, and the strong immunoexpression of androgen receptor in Sertoli cells of infant animals (aged 18-22 and 35 weeks) occurred when testosterone concentrations were at their lowest. This switch in the intensity of Sertoli cell androgen receptor immunoexpression is intriguing, as during both these periods the Sertoli cells are still immature (undifferentiated) and are capable of proliferation (Sharpe et al., 2000). Therefore, it is presumed that there are specific (unknown) reasons for minimizing androgen action on Sertoli cells during the period of the neonatal increase in testosterone concentrations.

The multicellular pattern of oestrogen receptor $\beta$ immunoexpression observed in the testes of adult marmosets in the present study supports the results of a recent detailed study of adult humans, macaques and marmosets (Saunders et al., 2001). Taylor and Al-Azzawi (2000) have also localized oestrogen receptor $\beta$ protein to 

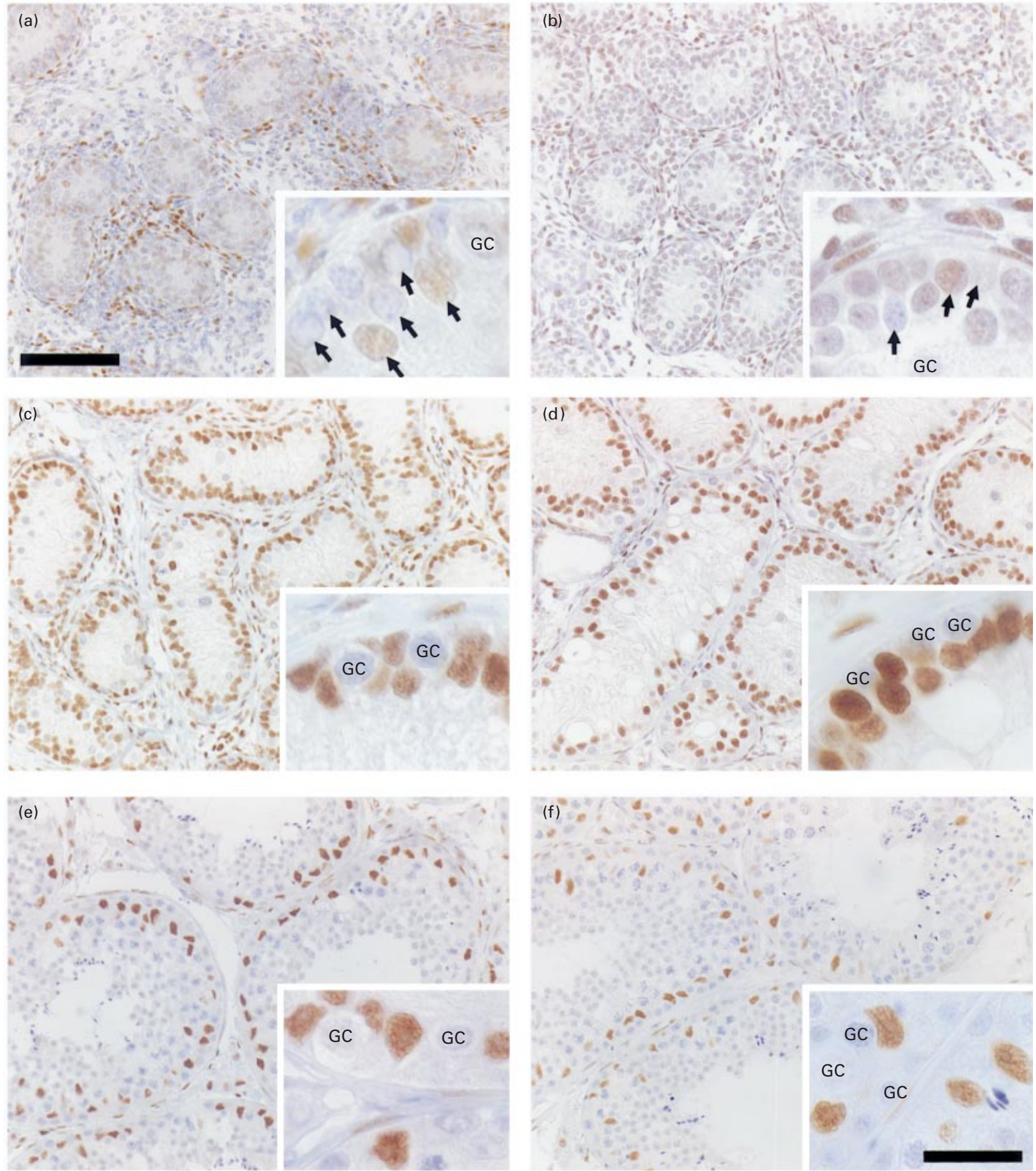

Fig. 2. Immunoexpression of androgen receptor in the testes of marmosets aged (a) 1 day (neonatal), (b) 6 weeks (neonatal), (c) 18 weeks (early infancy), (d) 35 weeks (late infancy), (e) 59 weeks (late pubertal) and (f) 112 weeks (adult). Note the weak immunostaining in the nuclei of some, but not all, Sertoli cells (arrows), and strong immunostaining in interstitial cells in (a) and (b). Note also the strong immunostaining in the nuclei of Sertoli cells at week 18 of age (c) and at all later ages. GC: germ cells. Scale bar represents $50 \mu \mathrm{m}$ (20 $\mu \mathrm{m}$ in insets)

adult human Sertoli cells and some types of germ cell, whereas another study in humans detected immunoexpression in Sertoli cells but not in germ cells of adult men (Pelletier and El-Alfy, 2000). However, there are no previous data on oestrogen receptor $\beta$ immunoexpression in the testis of immature humans and non-human primates. The results of the present study show that oestrogen receptor $\beta$ immunoexpression is also prominent in both the 
Table 2. Summary of oestrogen receptor $\beta$ immunoexpression in marmosets

\begin{tabular}{llccc}
\hline & & \multicolumn{3}{c}{$\begin{array}{c}\text { Intensity of oestrogen receptor } \\
\beta \text { immunoexpression* }\end{array}$} \\
\cline { 3 - 5 } Age & Stage of development & Sertoli cells & Germ cells & $\begin{array}{c}\text { Interstitial } \\
\text { cells }\end{array}$ \\
\cline { 3 - 5 } $1-4$ days & Neonatal & $+/++$ & ++ & ++ \\
$4-6$ weeks & Neonatal & $+/++$ & ++ & ++ \\
$18-22$ weeks & Early infancy & $+/++$ & ++ & ++ \\
35 weeks & Late infancy & $+/++$ & ++ & ++ \\
$58-62$ weeks & Late pubertal & $+/++$ & ++ & ++ \\
$>100$ weeks & Adult & $+/++$ & ++ & ++ \\
\hline
\end{tabular}

*Based on evaluation of four to five animals at each age. Immunoexpression was classified as: +: moderate; ++: strong.
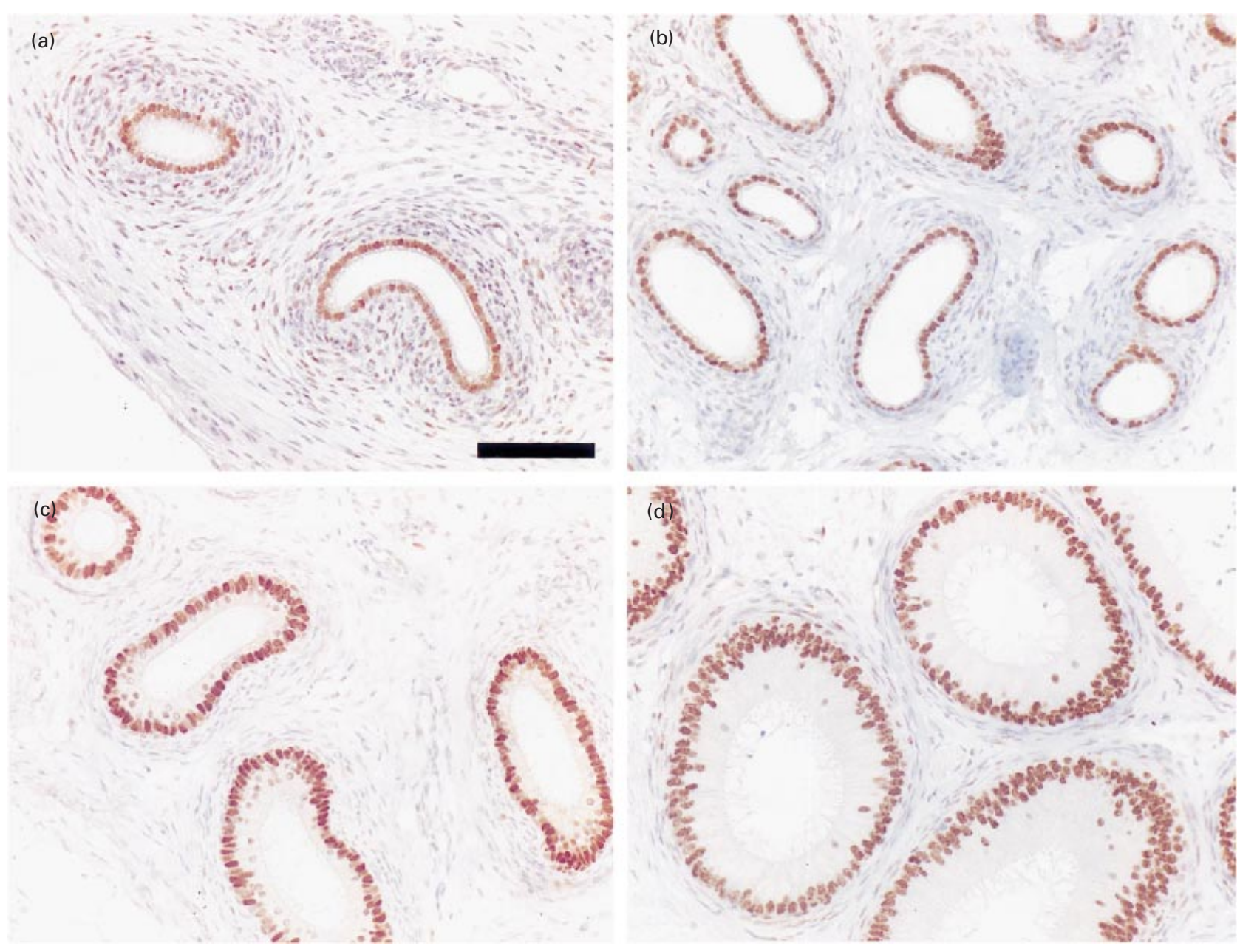

Fig. 3. Immunoexpression of androgen receptor in the epididymis of marmosets aged (a) 1 day (neonatal), (b) 4 weeks (neonatal), (c) 18 weeks (early infancy) and (d) 62 weeks (late pubertal). Very strong immunoexpression was observed consistently in epithelial cell nuclei at all ages. Scale bar represents $50 \mu \mathrm{m}$.

Sertoli cells and germ cells of neonatal marmosets, as well as at other ages, and indicate strongly that many Sertoli cells in neonatal marmosets are targets for oestrogens. On the basis of the relative levels of immunoexpression of androgen receptor and oestrogen receptor $\beta$ in neonatal Sertoli cells, it can be argued that oestrogens probably target neonatal Sertoli cells more than androgens do. This interpretation must be tempered by the fact that the precise relationship between the immunodetection of steroid receptors on tissue sections and their biological activity is unclear, and whether or not those receptors are activated by ligands, or merely have the potential for activation, is 

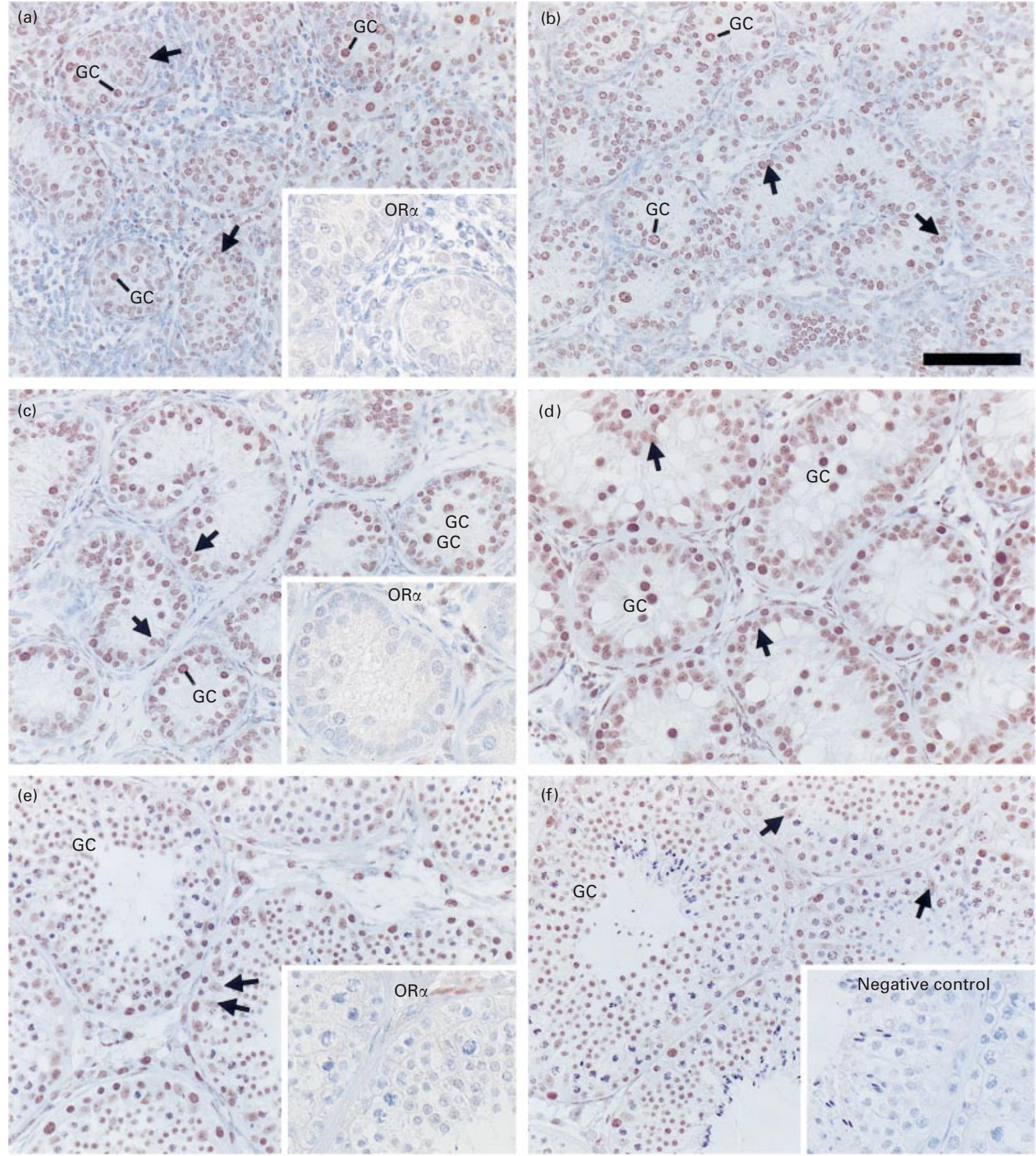

Fig. 4. Immunoexpression of oestrogen receptor $\beta$ in the testes of marmosets aged (a) 1 day (neonatal), (b) 6 weeks (neonatal), (c) 18 weeks (early infancy), (d) 35 weeks (late infancy), (e) 62 weeks (late pubertal) and (f) 112 weeks (adult). Note the prominent oestrogen receptor $\beta$ immunostaining in the nuclei of Sertoli cells (arrows) and germ cells (GC), as well as in interstitial cells, at all ages. For comparison, oestrogen receptor $\alpha\left(\mathrm{OR}_{\alpha}\right)$ immunostaining is shown in insets in (a), (c) and (e). Oestrogen receptor $\alpha$ immunostaining was found in only a few interstitial cells at all ages, and appeared to be cytoplasmic rather than nuclear. Inset in (f) shows a negative control. Scale bar represents $50 \mu \mathrm{m}$. 

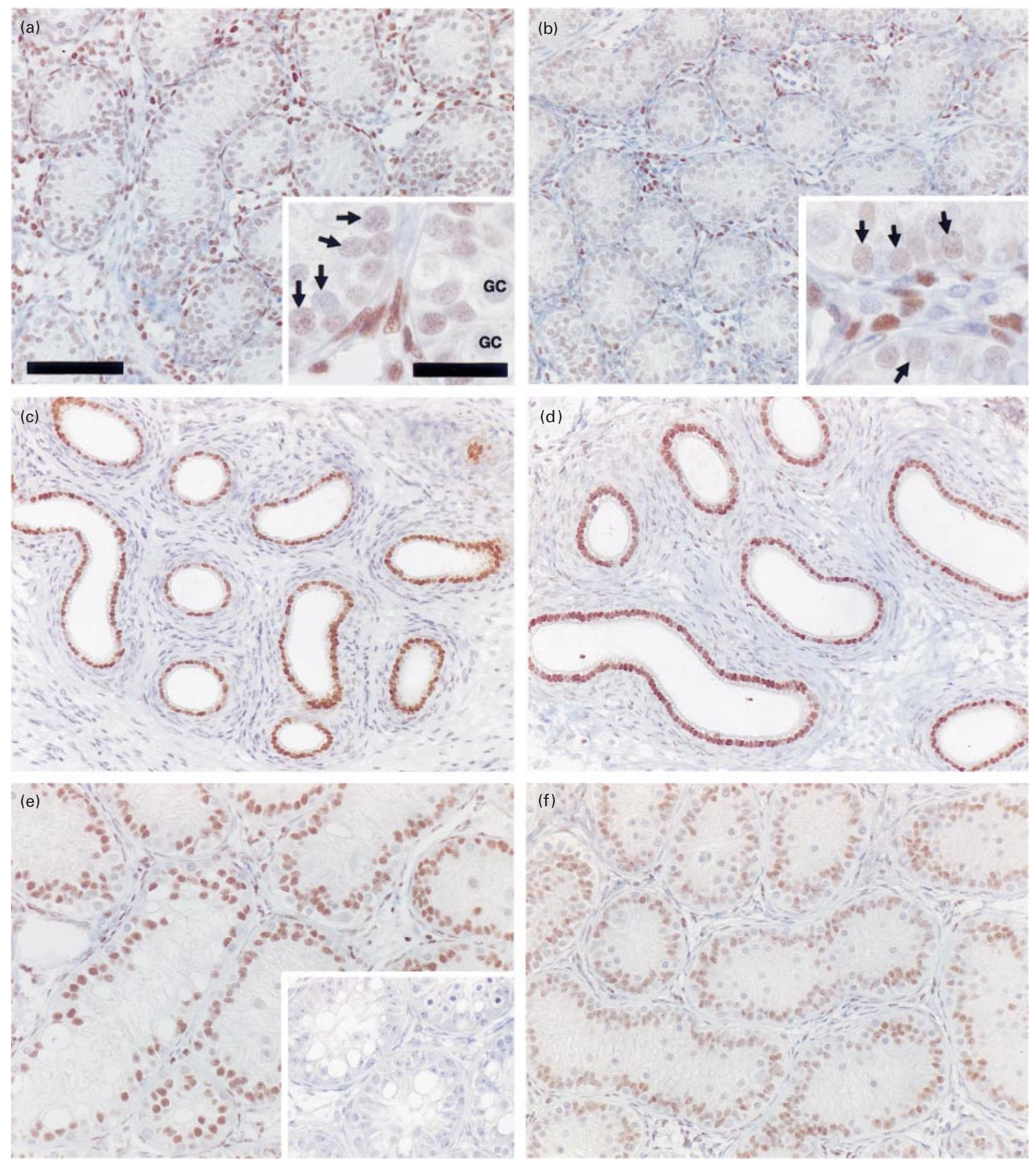

Fig. 5. Effect of treatment with vehicle (a,c,e; control) or a GnRH antagonist $(b, d, f)$, either from birth to week 4 of age or from week 25 to week 35 of age, on immunoexpression of androgen receptor in $(a, b)$ the testis and (c,d) epididymis of marmosets at week 4 of age (neonatal) and $(\mathrm{e}, \mathrm{f})$ in the testis at week 35 of age (late infancy). Androgen receptor immunostaining in Sertoli cells (arrows) and interstitial cells at week 4 of age was unaffected by treatment, but note the reduction in immunostaining, particularly in Sertoli cells, in GnRH antagonist-treated animals at week 35 of age (f). GnRH antagonist had no effect on androgen receptor immunoexpression in the epididymis at any age. Inset in (e) shows a negative control. Scale bar represents $50 \mu \mathrm{m}(20 \mu \mathrm{m}$ in insets in (a) and (b)). 
difficult to determine. However, it has been established that, in adult rats (Bremner et al., 1994), the intensity of androgen receptor immunoexpression in Sertoli cells is quantifiably related to the androgen dependence of Sertoli cell function at different stages of the spermatogenic cycle. Together with the results of other studies in which Sertoli cell and germ cell immunoexpression of oestrogen receptor $\beta$ in immature and adult rodents has been reported (Saunders et al., 1998; van Pelt et al., 1999; Bilinska et al., 2000, Jefferson et al., 2000), the results of the present study also indicate that an important role for oestrogens throughout development of the seminiferous epithelium is not confined to rodents.

Treatment with GnRH antagonist from birth to week 4 of age completely abolished the neonatal increase in plasma testosterone concentrations observed in control animals (Lunn et al., 1994), and treatment from week 25 to week 35 resulted in similar 'baseline' concentrations of testosterone in control and $\mathrm{GnRH}$ antagonist-treated co-twins (R. M. Sharpe, C. McKinnell, K. Morris and C. Kelnar, unpublished). However, only treatment during weeks 25-35 reduced androgen receptor immunoexpression, whereas immunoexpression of oestrogen receptor $\beta$ was unaffected by treatment during either period. These results, together with the fact that androgen receptor immunoexpression was not correlated with plasma testosterone concentrations in neonatal and infant marmosets, indicate that androgen receptor expression is not regulated by androgen in a straightforward manner in these animals, and that the high concentrations of plasma testosterone during the neonatal period are not absolutely necessary for the expression of androgen receptor in neonatal marmoset testis.

Previous studies have shown that neonatal treatment of male marmosets with $\mathrm{GnRH}$ antagonist has no long-term consequences in terms of adult sexual behaviour (Lunn et al., 1994) or fertility (Lunn et al., 1997), although germ cell volume per Sertoli cell was decreased in adulthood (Sharpe et al., 2000). However, in the short term, such treatment results in a reduction in the number of Sertoli cells per testis in early infancy (weeks 18-22 of age), reflecting suppression of Sertoli cell replication during the neonatal period (Sharpe et al., 2000). Therefore, the results of the present study, which show that GnRH antagonist treatment during infancy reduces androgen receptor immunoexpression in Sertoli cells in late infancy (week 35 of age), may indicate that $\mathrm{GnRH}$ antagonist treatment simply delays Sertoli cell maturation.

In conclusion, the results of the present study provide new data on the expression of androgen receptor and oestrogen receptor $\beta$ during neonatal life in a non-human primate. Androgen receptor expression is low or undetectable in neonatal Sertoli cells, whereas oestrogen receptor $\beta$ is immunoexpressed with reasonably high intensity in most, but not all, Sertoli cells. These results indicate that the Sertoli cells may be targets primarily for oestrogens, rather than androgens, during this period. Previous studies reporting the expression of androgen receptor protein in fetal human testes (Wilson and McPhaul,
1996) and in adult human Sertoli cells (Suarez-Quain et al., 1999) mean that it will be of particular interest to determine whether neonatal human Sertoli cells express androgen receptor. Our preliminary studies indicate that the situation is comparable to that in marmosets. Abolition of the normal increase in plasma testosterone concentrations in neonatal marmosets had no effect on androgen receptor immunoexpression in neonatal animals and the physiological significance of this increase remains unclear.

\section{References}

Abbott DH and Hearn JP (1978) Physical, hormonal and behavioural aspects of sexual development in the marmoset monkey (Callithrix jacchus). Journal of Reproduction and Fertility 53 155-166

Atanassova N, McKinnell C, Walker M, Turner KJ, Fisher JS, Morley M, Millar MR, Groome NP and Sharpe RM (1999) Permanent effects of neonatal estrogen exposure in rats on reproductive hormone levels, Sertoli cell number, and the efficiency of spermatogenesis in adulthood Endocrinology 140 5364-5373

Bilinska B, Schmalz-Fraczek B, Sadowska J and Carreau S (2000) Localisation of cytochrome P450 aromatase and oestrogen receptors alpha and beta in testicular cells: an immunohistochemical study of the bank vole Acta Histochemica 102 167-181

Bremner WJ, Millar MR, Sharpe RM and Saunders PTK (1994) Immunohistochemical localisation of androgen receptors in the rat testis: evidence for stage-dependent expression and regulation by androgens Endocrinology 135 1227-1234

Corker CS and Davidson DW (1981) Radioimmunoassay of testosterone in various biological fluids without chromatography Journal of Steroid Biochemistry 9 319-323

Cortes D, Muller J and Skakkebaek NE (1987) Proliferation of Sertoli cells during development of the human testis assessed by stereological methods International Journal of Andrology 10 589-596

Dixson AF (1986) Plasma testosterone concentrations during postnatal development in the male common marmoset Folia Primatologica 47 166-170

Fisher JS, Millar MR, Majdic G, Saunders PTK, Fraser HM and Sharpe RM (1997) Immunolocalisation of oestrogen receptor-alpha within the testis and excurrent ducts of the rat and marmoset monkey from perinatal life to adulthood Journal of Endocrinology 153 485-495

Forest MG, de Peretti E and Bertrand J (1976) Hypothalamicpituitary-gonadal relationships in man from birth to puberty Clinical Endocrinology 5 551-569

Jefferson WN, Couse JF, Banks EP, Korach KS and Newbold RR (2000) Expression of oestrogen receptor beta is developmentally regulated in reproductive tissues of male and female mice Biology of Reproduction $62310-317$

Lunn SF, Recio R, Morris K and Fraser HM (1994) Blockade of the neonatal rise in testosterone by a gonadotrophin-releasing hormone antagonist: effects on timing of puberty and sexual behaviour in the male marmoset monkey Journal of Endocrinology 141 439-447

Lunn SF, Cowen GM and Fraser HM (1997) Blockade of the neonatal rise in testosterone by a GnRH antagonist: the free androgen index, reproductive capacity and postmortem findings in the male marmoset monkey Journal of Endocrinology 154 125-131

McKinnell C, Atanassova N, Williams K, Fisher JS, Walker M, Turner KJ, Saunders PTK and Sharpe RM (2001) Suppression of androgen action and the induction of gross abnormalities of the reproductive tract in male rats treated neonatally with diethystilbestrol Journal of Andrology 22 323-338

Mann DR, Howie S, Paulsen DF, Akinbami MA, Lunn SF and Fraser HM (1998) Changes in lymphoid tissue after treatment with a gonadotropin releasing hormone antagonist in the neonatal marmoset (Callithrix jacchus). American Journal of Reproductive Immunology 39 256-265

Mann DR, Lunn SF, Akinbami MA, Samuel K, Waterfall M and Fraser HM (1999) Effect of neonatal treatment with a GnRH antagonist on 
development of the cell-mediated immune response in marmosets American Journal of Reproductive Immunology 42 175-186

Millar MR, Sharpe RM, Weinbauer GF, Fraser HM and Saunders PTK (2000) Marmoset spermatogenesis: organisational similarities to the human International Journal of Andrology 23 266-277

Norton AJ, Jordan S and Yeomans P (1994) Brief, high-temperature heat denaturation (pressure cooking): a simple and effective method of antigen retrieval for routinely processed tissues Journal of Pathology 173 $371-379$

Pelletier G and El-Alfy M (2000) Immunocytochemical localisation of estrogen receptors $\alpha$ and $\beta$ in the human reproductive organs Journal of Clinical Endocrinology and Metabolism 85 4835-4840

Rey R (1999) The prepubertal testis: a quiescent or a silently active organ? Histology and Histopathology 14 991-1000

Saunders PTK, Gaughan J, Saxty BA, Kerr LE and Millar MR (1996a) Expression of protamine P2 in the testis of the common marmoset and man visualised using non-radioactive in-situ hybridisation International Journal of Andrology 19 212-219

Saunders PTK, Millar MR, Majdic G, McLaren TT, Bremner WB, Grigor K and Sharpe RM (1996b) Testicular androgen receptor protein: distribution and control of expression. In Cellular and Molecular Control of Testicular Cells pp 213-229 Ed. C Desjardins. Springer-Verlag, New York

Saunders PTK, Fisher JS, Sharpe RM and Millar MR (1998) Expression of oestrogen receptor beta (ER $\beta$ ) occurs in multiple cell types, including some germ cells, in the rat testis Journal of Endocrinology 156 R13-R17

Saunders PTK, Millar MR, Williams K et al. (2000) Differential expression of estrogen receptor-alpha and -beta and androgen receptor in the ovaries of marmoset and human Biology of Reproduction 63 1098-1105

Saunders PTK, Sharpe RM, Williams K, Macpherson S, Urquart H, Irvine DS and Millar MR (2001) Differential expression of oestrogen receptor $\alpha$ and $\beta$ proteins in the testes and male reproductive system of human and non-human primates Molecular Human Reproduction 7 227-236
Sharpe RM, Walker M, Millar MR, Atanassova N, Morris K, McKinnell C, Saunders PTK and Fraser HM (2000) Effect of neonatal gonadotrophinreleasing hormone antagonist administration on Sertoli cell number and testicular development in the marmoset: comparison with the rat Biology of Reproduction 62 1685-1693

Suarez-Quian CA, Martinez-Garcia F, Nistal M and Regadera J (1999) Androgen receptor distribution in adult human testis Journal of Clinical Endocrinology and Metabolism 84 350-358

Taylor AH and Al-Azzawi F (2000) Immunolocalisation of oestrogen receptor beta in human tissues Journal of Molecular Endocrinology $\mathbf{2 4}$ 145-155

van Pelt AM, de Rooij DG, van der Burg B, van der Saag PT, Gustafsson JA and Kuiper GGJM (1999) Ontogeny of oestrogen receptor-beta expression in rat testis Endocrinology 140 478-483

Weinbauer GF, Aslam H, Krishnamurthy H, Brinkworth MH, Einspanier A and Hodges JK (2001) Quantitative analysis of spermatogenesis and apoptosis in the common marmoset (Callithrix jacchus) reveals high rates of spermatogonial turnover and high spermatogenic efficiency Biology of Reproduction 64 120-126

Williams K, Saunders PTK, Atanassova N, Fisher JS, Turner KJ, Millar MR, McKinnell C and Sharpe RM (2000) Induction of progesterone receptor immunoexpression in stromal tissue throughout the male reproductive tract after neonatal estrogen treatment of rats Molecular and Cellular Endocrinology 164 117-131

Wilson CM and McPhaul MJ (1996) A and B forms of the androgen receptor are expressed in a variety of human tissues Molecular and Cellular Endocrinology 18 51-57

Received 5 March 2001.

First decision 24 April 2001.

Accepted 21 May 2001 